\title{
The influence of artificial aging on the microstructure and hardness of an Al-Zn-Mg-Zr alloy processed by equal-channel angular pressing
}

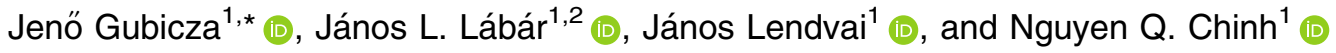 \\ ${ }^{1}$ Department of Materials Physics, ELTE Eötvös Loránd University, P.O.B. 32, Budapest 1518, Hungary \\ ${ }^{2}$ Institute for Technical Physics and Materials Science, Centre for Energy Research, Hungarian Academy of Sciences, Budapest, \\ Hungary
}

Received: 6 February 2019

Accepted: 17 April 2019

Published online:

29 April 2019

(C) The Author(s) 2019

\begin{abstract}
The effect of artificial aging on the microstructure and hardness of an ultrafinegrained (UFG) $\mathrm{Al}-4.8 \% \mathrm{Zn}-1.2 \% \mathrm{Mg}-0.14 \% \mathrm{Zr}$ (wt $\%$ ) alloy was studied. The UFG microstructure with an average grain size of about $260 \mathrm{~nm}$ was obtained by severe plastic deformation applying four passes of equal-channel angular pressing (ECAP) at room temperature. Then, artificial aging was performed on the ECAP-processed samples at $120^{\circ} \mathrm{C}$ and $170{ }^{\circ} \mathrm{C}$ for $2 \mathrm{~h}$. In the ECAP-processed sample GuinierPreston (GP) zones, $\mathrm{MgZn}_{2}$ precipitates and a high dislocation density were observed. After aging at $120^{\circ} \mathrm{C}$, coarse $\mathrm{MgZn}$, precipitates were formed in the grain boundaries, leading to softening, while the dislocation density did not decrease. Annealing at $170{ }^{\circ} \mathrm{C}$ yielded a growth of the matrix grains to $\sim 530 \mathrm{~nm}$ with a significant decrease in the dislocation density. In addition, GP zones disappeared and $\mathrm{MgZn} \mathrm{n}_{2}$ precipitates were formed in both the grain interiors and the boundaries. This overaging of the precipitate structure and the decrease in the dislocation density resulted in a lower hardness than after annealing at $120^{\circ} \mathrm{C}$. It was found that the hardness reduction due to the change of the precipitate structure at $170{ }^{\circ} \mathrm{C}$ was higher than that caused by the decrease in the dislocation density.
\end{abstract}

\section{Introduction}

There is a large interest in age-hardenable $\mathrm{Al}-\mathrm{Zn}-\mathrm{Mg}$ alloys (7xxx series) due to their technological and practical importance, as these alloys can be treated to have a preferable combination of ductility and strength, as well as reasonable weldability and corrosion resistance. If a supersaturated $\mathrm{Al}-\mathrm{Zn}-\mathrm{Mg}$ alloy is aged under different conditions, various metastable and stable precipitates may form [1-8]. Therefore, aging can be used for tailoring the

This work was dedicated to Prof. T. G. Langdon on the occasion of his 80th birthday.

Address correspondence to E-mail: jeno.gubicza@ttk.elte.hu 
mechanical behavior of these alloys. Since the supersaturated state is thermodynamically unstable, the aging process may start at room temperature (RT) immediately after solution treatment and quenching. The decomposition of the supersaturated solid solution (SSSS) takes place by the formation of GuinierPreston (GP) zones at RT. For higher aging temperatures (typically between 80 and $150{ }^{\circ} \mathrm{C}$ ), metastable intermediate $\eta^{\prime}$ particles are formed directly from the SSSS and/or mediately from the GP zones. At higher temperatures, the formation of stable $\eta$ precipitates with a composition of $\mathrm{MgZn}_{2}$ is expected. It should be emphasized that significant strengthening can be achieved by the formation of GP zones and/or $\eta^{\prime}$ particles. For an effective application of aging on tailoring the mechanical properties of $\mathrm{Al}-$ $\mathrm{Zn}-\mathrm{Mg}$ alloys, it is necessary to know the influence of the chemical composition and the history of the sample (e.g., pre-deformation) on the precipitation during aging.

Considering the promoting effect of dislocations on precipitation, a small amount of pre-strain is usually applied to the samples by conventional tension or compression in order to enhance the probability of the formation of metastable precipitates during subsequent natural aging [9]. In the last two decades, severe plastic deformation (SPD) by equal-channel angular pressing (ECAP) was applied to change the microstructure, thereby improving the mechanical properties (both strength and ductility) of supersaturated alloys [10-16]. This procedure imposes a large strain on the sample, causing a high dislocation density and also resulting in an ultrafine-grained (UFG) microstructure, thereby improving the strength of metallic materials. Although the microstructure obtained by ECAP has been extensively studied in the literature, the effect of artificial aging on the precipitation and the strength of SPDprocessed supersaturated $\mathrm{Al}-\mathrm{Zn}-\mathrm{Mg}$ alloys have not been clarified so far.

In this paper, the effect of artificial aging on the microstructure and hardness of an UFG $\mathrm{Al}-4.8 \% \mathrm{Zn}-$ $1.2 \% \mathrm{Mg}-0.14 \% \mathrm{Zr}(\mathrm{wt} \%)$ alloy is studied. The UFG microstructure was obtained by four passes of ECAP at RT. Then, the ECAP-processed billets were aged at $120{ }^{\circ} \mathrm{C}$ and $170{ }^{\circ} \mathrm{C}$ for $2 \mathrm{~h}$ as these aging conditions are often applied on the homogenized undeformed counterparts of this alloy [4, 17]. The influence of aging on the grain size, dislocation density and precipitate structure was investigated for both temperatures. The changes in the microstructure caused by aging were correlated with the hardness variation.

\section{Materials and methods}

\section{Processing of the samples}

An alloy with the composition of $\mathrm{Al}-4.8 \% \mathrm{Zn}-$ $1.2 \% \mathrm{Mg}-0.14 \% \mathrm{Zr}$ (wt \%) was processed by casting. The addition of the small amount of $\mathrm{Zr}$ can ensure a fine-grained structure [18-21]. The as-cast material was homogenized in air at $470{ }^{\circ} \mathrm{C}$ for $8 \mathrm{~h}$ and then hot-extruded to a sheet of $10 \times 40 \mathrm{~mm}^{2}$ cross section at $380{ }^{\circ} \mathrm{C}$. The average grain size in the extruded material was about $10 \mu \mathrm{m}$. Cylindrical billets with $10 \mathrm{~mm}$ in diameter and $70 \mathrm{~mm}$ in length were fabricated from the extruded sheet, then subjected to solution heat treatment at $470{ }^{\circ} \mathrm{C}$ for $30 \mathrm{~min}$ and water-quenched in order to receive a supersaturated solid solution. The samples were processed by ECAP at RT for 4 passes within 10 min after quenching. The ECAP die had an internal channel angle of $90^{\circ}$ and an outer arc of curvature at the intersection of the two parts of the channel of $20^{\circ}$, giving an imposed strain of about 1 on each separate pass [22]. The samples were processed following route $B_{c}$ in which the billets are rotated in the same sense around their longitudinal axes by $90^{\circ}$ after each pass [23]. The ECAPprocessed samples were stored at RT for a long period (about 1 year) and then artificially aged at $120^{\circ} \mathrm{C}$ or $170{ }^{\circ} \mathrm{C}$ for $2 \mathrm{~h}$ in an oil-bath.

\section{Microstructure characterization techniques}

The phase composition of the ECAP-processed and the aged specimens were studied by $X$-ray diffraction (XRD) using a Philips Xpert powder diffractometer with $\mathrm{CuK} \alpha$ radiation (wavelength: $\lambda=0.15418 \mathrm{~nm}$ ).

The microstructure was characterized by $X$-ray line profile analysis (XLPA) using a high-resolution diffractometer (type: MultiMax-9, manufacturer: Rigaku, Japan) with $\mathrm{CuK} \alpha_{1}$ radiation (wavelength: $\lambda=0.15406 \mathrm{~nm}$ ). The diffraction patterns were then evaluated by the Convolutional Multiple Whole Profile (CMWP) fitting procedure [24]. In the CMWP method, the experimental diffraction pattern is fitted by the sum of a background spline and the convolution of the instrumental pattern and the theoretical 
line profiles related to the diffraction domain size and the lattice strain caused by dislocations. The instrumental pattern was measured on $\mathrm{LaB}_{6}$ line profile standard material. The area-weighted mean diffraction domain size $\left(\langle x\rangle_{\text {area }}\right)$ and the average dislocation density $(\rho)$ were determined from the line profile fitting. The area-weighted mean diffraction domain size was calculated as $\langle x\rangle_{\text {area }}=m \cdot \exp \left(2.5 \sigma^{2}\right)$, where $m$ is the median and $\sigma^{2}$ is the log-normal variance of the diffraction domain size distribution.

The size and morphology of the matrix grains and the precipitates were characterized by transmission electron microscopy (TEM). Thin TEM lamellae were prepared from pieces of the bulk samples by Ar-ion milling with special care taken to avoid heating (and possible transformation) of the samples during preparation. Firstly, the samples were glued by using a special glue at $100{ }^{\circ} \mathrm{C}$ for not more than $1 \mathrm{~min}$ to a $\mathrm{Cu}$ stub for mechanical grinding and polishing. In the second step, ion-beam thinning of the $50-\mu \mathrm{m}$-thick lamella was started at $7 \mathrm{keV}$ using $2 \mathrm{~mA}$ ion current. Finally, the just perforated lamella was cleaned at $3 \mathrm{keV}$ and later at $1 \mathrm{keV}$ from both sides to remove damaged layers from its surfaces.

The TEM, high-resolution TEM (HRTEM) and energy-disperse X-ray spectroscopy (EDS) examinations were performed in a Titan Themis G2 200 scanning TEM (STEM) equipped with a four-segment Super-X EDS detector. The corrector for the spherical aberration $\left(C_{\mathrm{s}}\right)$ was applied at the imaging part, while no probe correction was present. Image resolution limit is $0.08 \mathrm{~nm}$ in phase-contrast HRTEM mode, while resolution is $0.16 \mathrm{~nm}$ in STEM Z-contrast imaging mode (recorded with a Fischione high-angle annular dark-field (HAADF) detector). HRTEM images were recorded at $200 \mathrm{keV}$ with a $4 \mathrm{k} \times 4 \mathrm{k}$ CETA 16 CMOS camera controlled by VELOX software. EDS data were recorded (together with the HAADF signal) in spectrum image (SI) mode, where individual X-ray count data can later be post-processed pixel-by-pixel and elemental intensities (and quantified elemental concentrations) can be obtained from any post-selected regions. In that way, distribution of concentrations can be visualized along any lines or over any area and the values can also be obtained in a tabulated form.

\section{Hardness testing}

The microhardness of the samples was measured at RT using a ZwickRoell $\mathrm{ZH} \mu$ hardness tester with a Vickers indenter, an applied load of $500 \mathrm{~g}$ and a dwell time of $10 \mathrm{~s}$. The average hardness values were obtained from at least 10 individual measurements.

\section{Experimental results}

\section{XRD study of the phase composition and the microstructure characteristics}

Figure 1 shows XRD patterns obtained on the ECAPprocessed and the aged specimens. In order to a better visibility of the peaks of the precipitates, only a part of the diffractograms (for the diffraction angle range $2 \theta=34-48^{\circ}$ ) is shown with logarithmic intensity scale. It is noted that the entire $2 \theta$ range of the measured patterns spreads from $15^{\circ}$ to $140^{\circ}$. Figure 1 reveals that in addition to the peaks of the face-centered cubic (fcc) Al matrix, X-ray reflections of a secondary phase also appeared on the diffractogram taken on the ECAP-processed sample. This phase was identified as $\eta-\mathrm{MgZn}_{2}$ with hexagonal close packed $(h c p)$ structure and lattice constants $a=0.5223 \mathrm{~nm}$ and $c=0.8568 \mathrm{~nm}$ (PDF card number: 34-0457). Peaks of $\eta^{\prime}$ precipitates were not detected (PDF card number: 31-0024). The ratio of the sums of the peak intensities (the areas under the peaks after background subtraction) of the $\mathrm{MgZn}_{2}$ precipitates and the matrix is shown in Table 1 . This ratio is

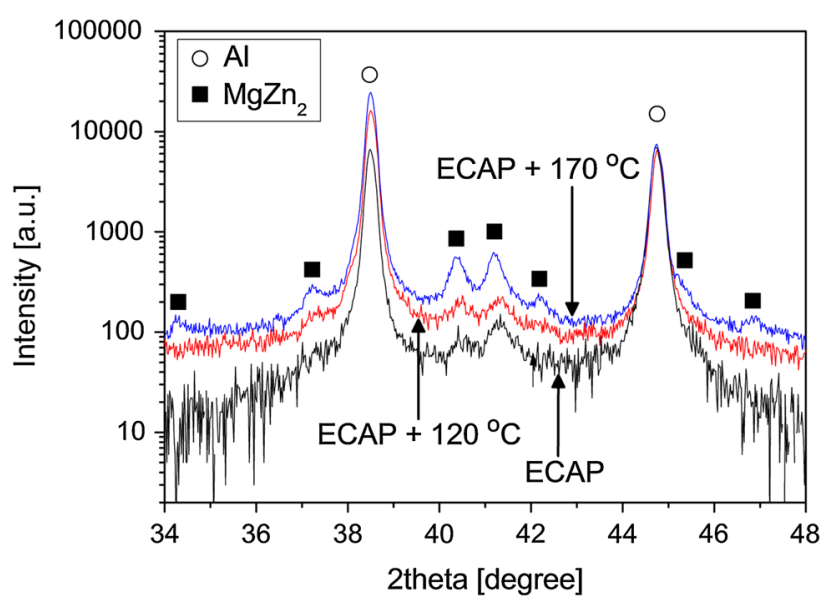

Figure 1 A part of the XRD patterns measured on the ECAPprocessed sample and the specimens aged at 120 and $170{ }^{\circ} \mathrm{C}$ for $2 \mathrm{~h}$. 
$0.9 \pm 0.2 \%$ for the specimen processed by four passes of ECAP. It is noted that this value is not equivalent to the volume ratio of the two phases as the unit volumes of the crystalline phases with different structures and chemical compositions usually scatter $X$-rays with different intensities. Nevertheless, the change of the fraction of precipitates during aging can be monitored using this quantity. Figure 1 shows that the peaks of the $\mathrm{MgZn}_{2}$ phase also appeared in the diffractograms obtained for the aged samples. The intensity fraction of this phase remained unchanged after annealing at $120{ }^{\circ} \mathrm{C}(0.9 \pm 0.2 \%)$, but it increased considerably to $6.8 \pm 0.9 \%$ after aging at $170{ }^{\circ} \mathrm{C}$.

As an example of the XLPA evaluation, Fig. 2 shows the measured XRD pattern and the fitted diffractogram obtained by the CMWP method for the ECAP specimen aged at $170{ }^{\circ} \mathrm{C}$. The average diffraction domain size and dislocation density determined by the CMWP fitting procedure for the three studied samples are listed in Table 1. After ECAP processing, the diffraction domain size was about $100 \mathrm{~nm}$ which remained unchanged during aging at both temperatures. The dislocation density in the ECAP-processed specimen was $\sim 5 \times 10^{14} \mathrm{~m}^{-2}$. This value did not change significantly during annealing at $120^{\circ} \mathrm{C}$. At the same time, aging at $170{ }^{\circ} \mathrm{C}$ yielded a decrease in the dislocation density to $\sim 3.3 \times 10^{14} \mathrm{~m}^{-2}$.

\section{Investigation of the microstructure by TEM}

Figure 3a shows a TEM image on the microstructure of the ECAP-processed sample. The average grain size of the matrix was about $260 \pm 30 \mathrm{~nm}$ as determined by TEM (also listed in Table 1). The average grain size was obtained from about twenty grains for

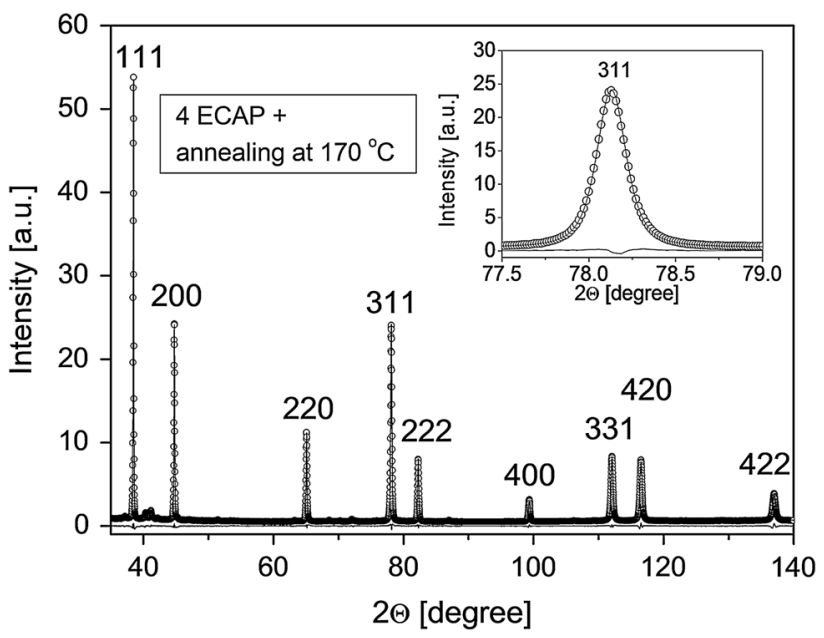

Figure 2 The measured XRD pattern (open circles) and the diffractogram fitted by the CMWP method (solid line) for the ECAP specimen aged at $170^{\circ} \mathrm{C}$. The difference between the measured and fitted data can be seen at the bottom of the figure. In order to a better visibility of the fitting quality, the inset shows the magnified reflection 311 .

each sample. It should be noted that in the present samples the grain size obtained by TEM was about 3-5 times larger than the diffraction domain size evaluated by XLPA. This difference is usual in SPDprocessed materials as the diffraction domains correspond to subgrains and/or dislocation cells inside the grains [25]. The ECAP-processed specimen contains precipitates, mainly in the interiors of the grains, as illustrated by the bright areas in Fig. 3a. Some larger particles can be found at the grain boundaries. Figure $3 b$ shows that inside the grains there are smaller precipitates with a size of $\sim 2 \mathrm{~nm}$ and larger particles with a diameter of about 10-20 nm. The corresponding EDS elemental maps for $\mathrm{Al}, \mathrm{Zn}, \mathrm{Mg}$ and $\mathrm{Zr}$ are shown in Fig. 3c-f, respectively. The white and black arrows in Fig. $3 \mathrm{~b}$

Table 1 The XRD intensity fraction of $\mathrm{MgZn}_{2}$ precipitates as well as the diffraction domain size and the dislocation density in the $\mathrm{Al}$ matrix as determined by XLPA. The average grain size values in the matrix determined by TEM are also shown

\begin{tabular}{|c|c|c|c|c|}
\hline Samples & $\begin{array}{l}\text { Intensity fraction of } \\
\operatorname{MgZn}_{2}(\%)\end{array}$ & $\begin{array}{l}\text { Diffraction domain size in } \\
\text { the matrix }(\mathrm{nm})\end{array}$ & $\begin{array}{l}\text { Dislocation density in the } \\
\text { matrix }\left(10^{14} \mathrm{~m}^{-2}\right)\end{array}$ & $\begin{array}{l}\text { Grain size in the matrix } \\
\text { from TEM }(\mathrm{nm})\end{array}$ \\
\hline 4 ECAP at RT & $0.9 \pm 0.2$ & $92 \pm 10$ & $4.8 \pm 0.5$ & $260 \pm 30$ \\
\hline $\begin{array}{l}4 \text { ECAP }+ \text { aged } \\
\text { at } 120{ }^{\circ} \mathrm{C}\end{array}$ & $0.9 \pm 0.2$ & $105 \pm 11$ & $5.0 \pm 0.5$ & $310 \pm 50$ \\
\hline $\begin{array}{l}4 \text { ECAP }+ \text { aged } \\
\text { at } 170{ }^{\circ} \mathrm{C}\end{array}$ & $6.8 \pm 0.9$ & $111 \pm 12$ & $3.3 \pm 0.4$ & $530 \pm 50$ \\
\hline
\end{tabular}



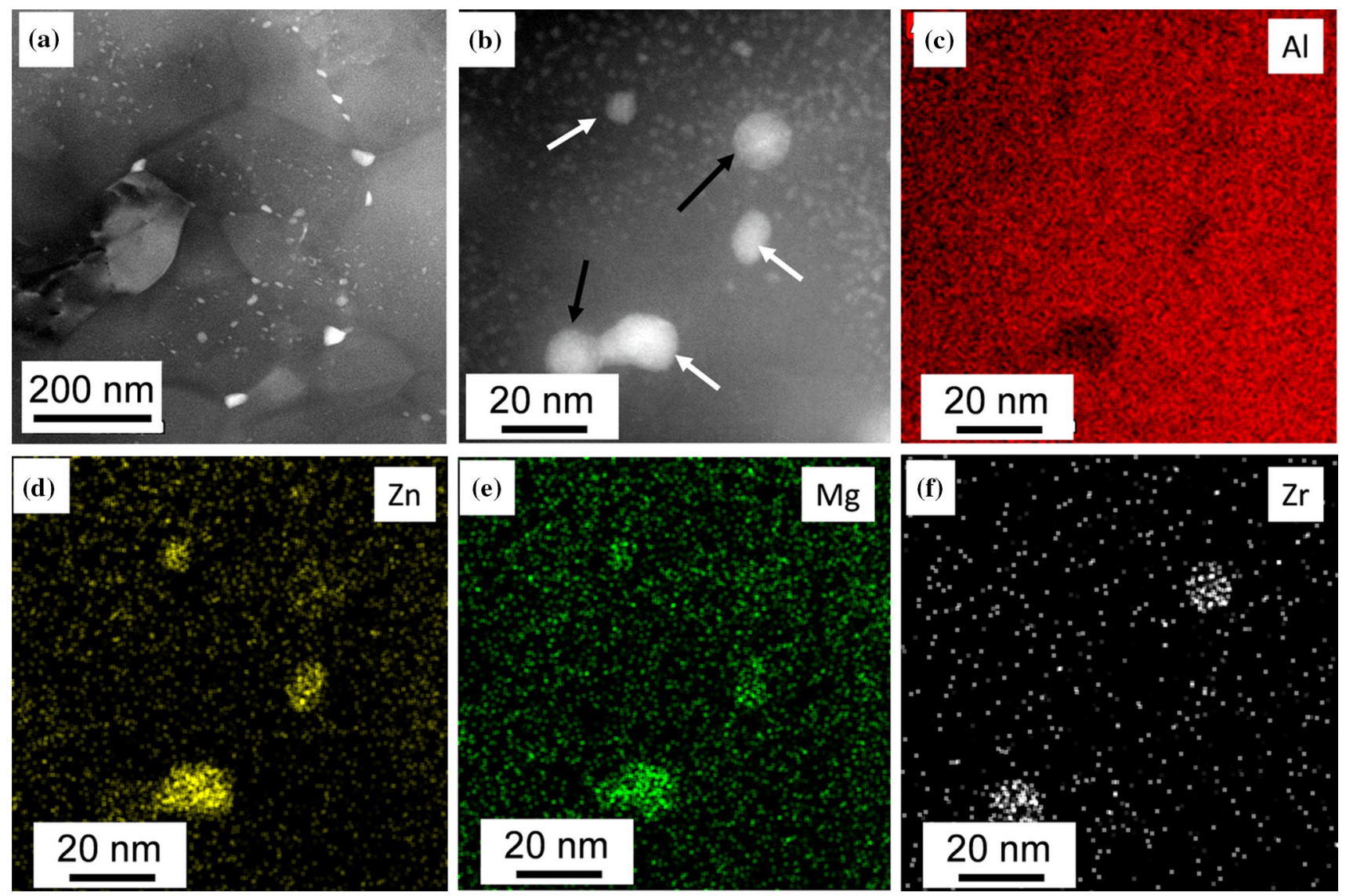

Figure 3 a HAADF STEM image illustrating the microstructure of the ECAP-processed sample. $\mathbf{b}$ HAADF STEM image with a higher magnification showing precipitates. $\mathbf{c}-\mathbf{f}$ EDS elemental

indicate $\mathrm{Mg} / \mathrm{Zn}$ - and $\mathrm{Zr}$-rich precipitates, respectively. The $\mathrm{Mg} / \mathrm{Zn}$-rich precipitates are depleted of $\mathrm{Al}$ as shown in Fig. 3c. Therefore, these particles are most probably the $\mathrm{MgZn}_{2}$ precipitates identified by XRD (see Fig. 1). The size of these particles is between 10 and $20 \mathrm{~nm}$ in good accordance with the apparent diffraction domain size value estimated from the breadths of the XRD peaks of this phase $(\sim 20 \mathrm{~nm})$. The size of the Zr-rich precipitates was $10-15 \mathrm{~nm}$ as shown in Fig. 3b. The XRD peaks of this phase were not revealed in the diffractograms since the fraction of the $\mathrm{Zr}$-rich phase must be low due to the small overall concentration of $\mathrm{Zr}(0.14 \mathrm{wt} \%)$. Similar Zr-rich precipitates were identified formerly as $\mathrm{Al}_{3} \mathrm{Zr}$ particles [26]. Previous studies (e.g., [20, 21]) have shown that the coherent $\mathrm{Al}_{3} \mathrm{Zr}$ precipitates pin effectively the grain boundaries formed in SPD processing, thereby preventing grain coarsening during annealing. In addition to $\mathrm{MgZn}_{2}$ and $\mathrm{Zr}$-rich particles, many small precipitates with the size of about maps for Al, Zn, Mg and $\mathrm{Zr}$ obtained on the area shown in $\mathbf{b}$. The white and black arrows in $\mathbf{b}$ indicate $\mathrm{Mg} / \mathrm{Zn}$ - and $\mathrm{Zr}$-rich precipitates, respectively.

$2 \mathrm{~nm}$ appeared inside the matrix grains (see Fig. 3b). Most probably, these particles are GP zones.

Figure $4 \mathrm{a}$ shows the microstructure of the ECAPprocessed sample aged at $120{ }^{\circ} \mathrm{C}$ for $2 \mathrm{~h}$. The grain size determined from the TEM images was $310 \pm 50 \mathrm{~nm}$ (see also Table 1) which does not differ significantly from the value obtained immediately after ECAP $(260 \pm 30 \mathrm{~nm})$. Figure $4 \mathrm{~b}$ also reveals that the grain boundaries are decorated with particles having size between 10 and $30 \mathrm{~nm}$. The elemental maps in Fig. 4c-f show that these precipitates are enriched with $\mathrm{Zn}$ and $\mathrm{Mg}$. The chemical analysis and the XRD results (see Fig. 1) suggest that these particles in the grain boundaries are $\eta-\mathrm{MgZn}_{2}$ precipitates. It is noted that similar particles also exist in the grain interiors but the larger ones can be found in the grain boundaries. In addition to $\mathrm{MgZn}_{2}$ precipitates, the grains also contain GP zones with the size of about $2 \mathrm{~nm}$. It must also be noted that in the vicinity of the grain boundaries the matrix was depleted of 

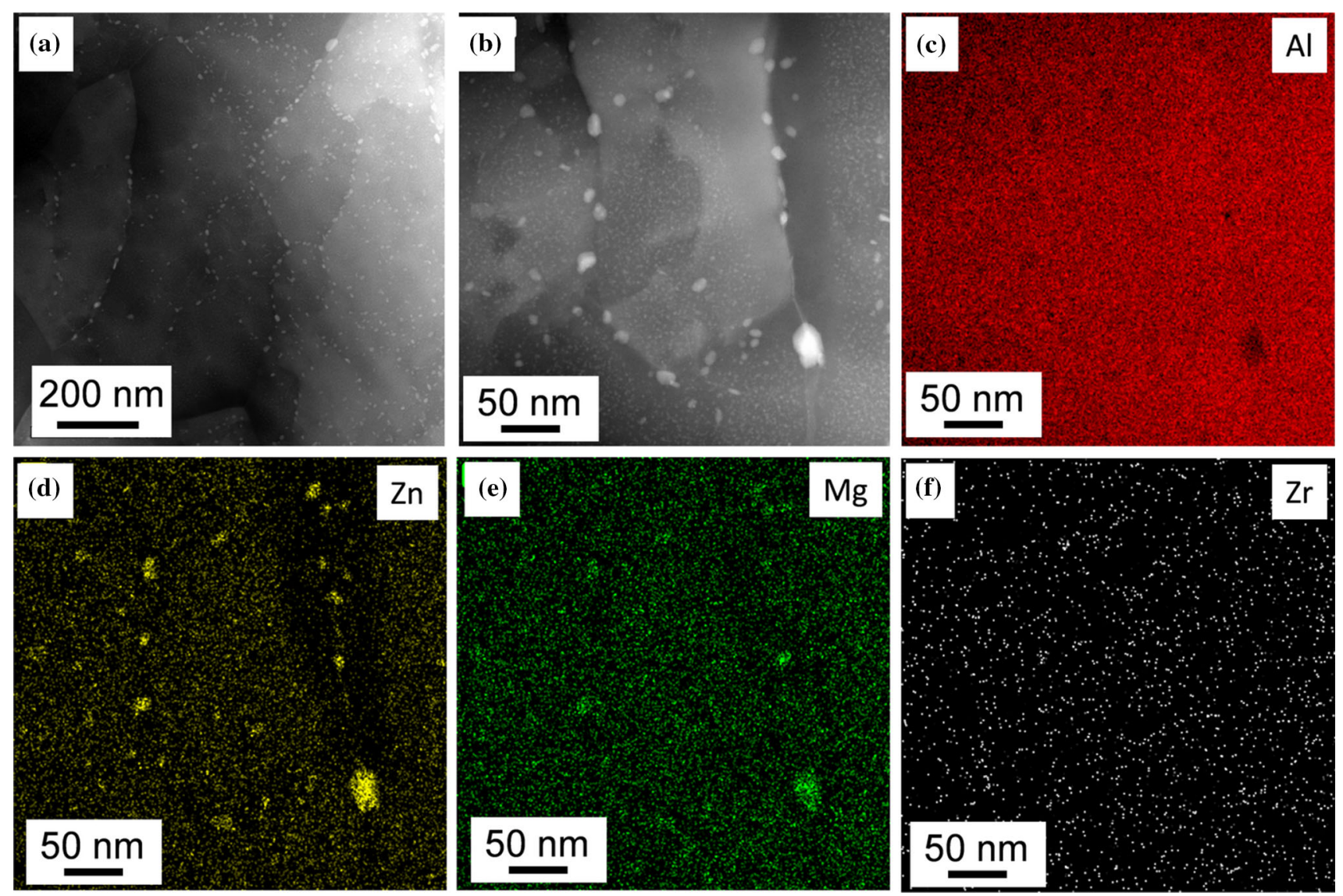

Figure 4 a HAADF STEM image illustrating the microstructure of the specimen processed by ECAP and then aged at $120{ }^{\circ} \mathrm{C}$ for 2 h. b HAADF STEM image with a higher magnification showing

GP zones as well as $\mathrm{Mg}$ and $\mathrm{Zn}$ atoms (e.g., see the area around the approximately vertical grain boundary at the right side of Fig. 4 b, d, e).

During aging at $170{ }^{\circ} \mathrm{C}$, the grain size increased to $530 \pm 50 \mathrm{~nm}$ as determined by TEM (see Table 1). As an example, Fig. 5a shows a TEM image which also reveals that both the grain boundaries and the grain interiors contain large $(10-100 \mathrm{~nm})$ precipitates. In Fig. $5 b$, the image with a higher magnification shows particles inside a grain with sizes between 5 and $30 \mathrm{~nm}$. The elemental maps in Fig. $5 \mathrm{c}-\mathrm{f}$ reveal that these particles are $\mathrm{Zn}$ - and $\mathrm{Mg}$-rich precipitates. Considering the result of the XRD phase analysis (see Fig. 1), these precipitates are identified as $\eta-\mathrm{MgZn}_{2}$ particles. The morphology of the large $\mathrm{Zn} / \mathrm{Mg}$-rich precipitates in the left bottom corner of Fig. $5 \mathrm{~b}$ suggests that these particles are disks with a hexagonal shape, i.e., the morphology at some extent reflects their hcp crystal structure. GP zones were not observed in the sample aged at $170{ }^{\circ} \mathrm{C}$. precipitates. c-f EDS elemental maps for $\mathrm{Al}, \mathrm{Zn}, \mathrm{Mg}$ and $\mathrm{Zr}$ obtained on the area shown in $\mathbf{b}$.

\section{Hardness of the ECAP-processed and the aged specimens}

The hardness of the ECAP-processed specimen was $1470 \pm 40 \mathrm{MPa}$ which decreased significantly to $1230 \pm 40 \mathrm{MPa}$ due to aging at $120^{\circ} \mathrm{C}$ for $2 \mathrm{~h}$. The annealing at the higher temperature of $170{ }^{\circ} \mathrm{C}$ resulted in a considerably lower hardness with the value of $1100 \pm 30 \mathrm{MPa}$. The reasons of the softening will be discussed in the next section.

\section{Discussion}

The present study revealed that the microstructure of the matrix in the ECAP-processed $\mathrm{Al}-4.8 \% \mathrm{Zn}-$ $1.2 \% \mathrm{Mg}-0.14 \% \mathrm{Zr}(\mathrm{wt} \%)$ alloy exhibited a good stability during aging at 120 and $170{ }^{\circ} \mathrm{C}$ for $2 \mathrm{~h}$. Indeed, the grain size and the dislocation density remained practically unchanged during annealing at $120{ }^{\circ} \mathrm{C}$ 

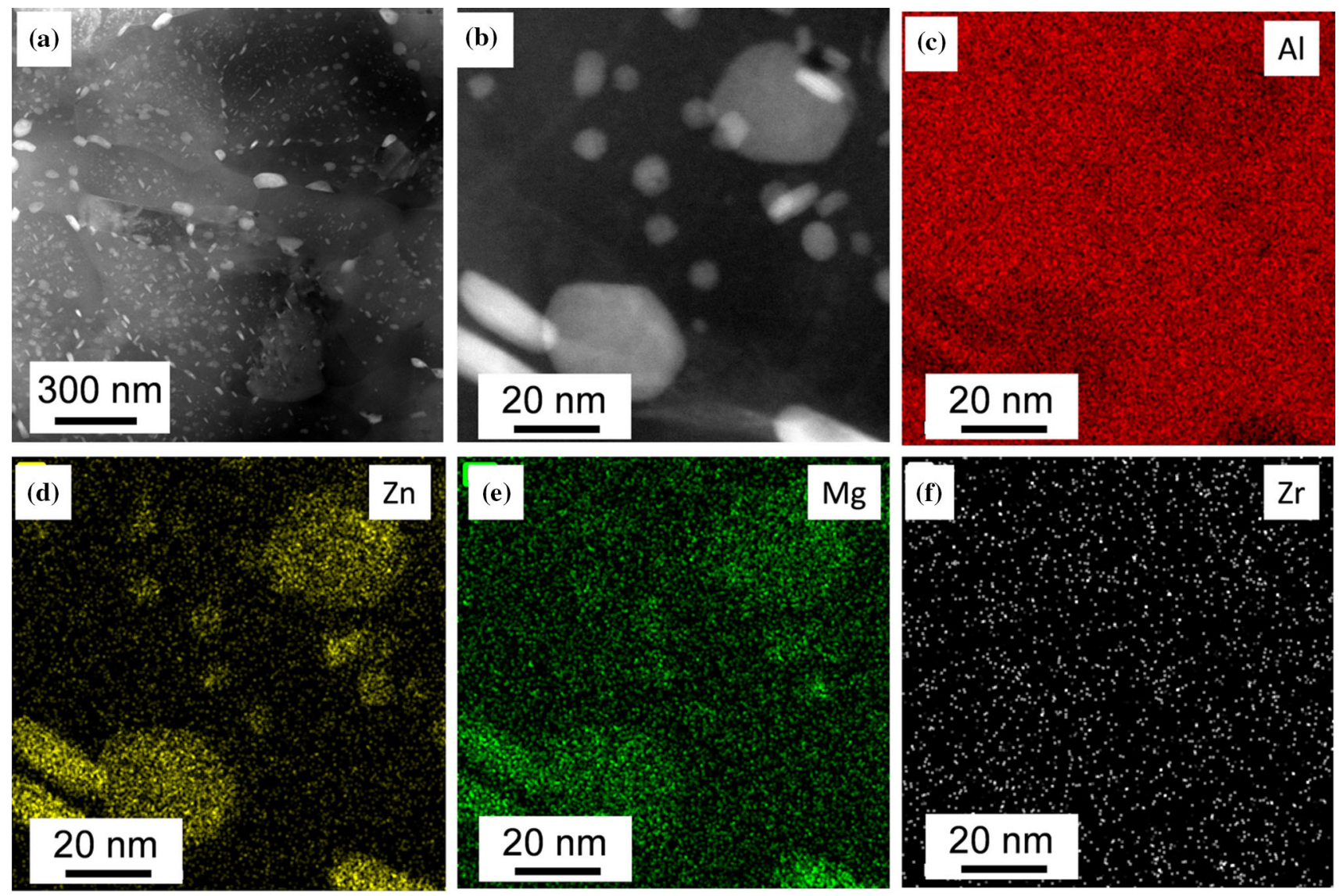

Figure 5 a HAADF STEM image illustrating the microstructure of the specimen processed by ECAP and then aged at $170{ }^{\circ} \mathrm{C}$ for 2 h. b HAADF STEM image with a higher magnification showing

and the dislocation density decreased only moderately at $170{ }^{\circ} \mathrm{C}$. At this temperature, there was a significant grain growth from $260 \pm 30$ to $530 \pm 50 \mathrm{~nm}$; nevertheless, the grain size remained in the UFG regime. The good thermal stability of the ECAP-processed alloy can be attributed to the hindering effect of precipitates (GP zones and $\mathrm{MgZn}_{2}$ particles) on movement of lattice defects (dislocations and grain boundaries), thereby retarding dislocation annihilation and grain growth. This effect operates even if ECAP processing is performed on supersaturated solid solutions since SPD promotes precipitation in dispersion-strengthened alloys [27]. Indeed, in an $\mathrm{Al}-4.8 \% \mathrm{Zn}-1.2 \% \mathrm{Mg}-0.14 \% \mathrm{Zr}$ alloy quenched to RT after annealing at $470{ }^{\circ} \mathrm{C}$ for $30 \mathrm{~min}$ and stored at RT for 1 year only GP zones and a few Zr-rich particles were observed as revealed by XRD (not shown here) and TEM (see Fig. 6). At the same time, in the alloy processed by four passes of ECAP after quenching and then stored at RT for 1 year a precipitates. c-f EDS elemental maps for $\mathrm{Al}, \mathrm{Zn}, \mathrm{Mg}$ and $\mathrm{Zr}$ obtained on the area shown in $\mathbf{b}$.

considerable amount of $\mathrm{MgZn}_{2}$ particles was formed (see Fig. 3).

Aging of the ECAP-processed sample at 120 and $170{ }^{\circ} \mathrm{C}$ for $2 \mathrm{~h}$ resulted in a change of the precipitate structure. At $120^{\circ} \mathrm{C}$ considerable change in the fraction of $\mathrm{MgZn}_{2}$ phase was not observed by XRD, but TEM revealed coarsening of these precipitates. This process was most significant at the grain boundaries which can be explained by the accelerated diffusion along these boundaries in the UFG microstructure. As a result, an inhomogeneous spatial distribution of precipitates was observed in the sample annealed at $120{ }^{\circ} \mathrm{C}$ for $2 \mathrm{~h}$. At the higher aging temperature of $170{ }^{\circ} \mathrm{C}$, the diffusion rate was high enough even inside the grains for resulting in a more homogeneous precipitate structure where relatively large $\mathrm{MgZn}_{2}$ particles $(\sim 30 \mathrm{~nm}$ ) can be found in both the grain interiors and the boundaries.

The hardness of the ECAP-processed alloy decreased from $1470 \pm 40$ to $1230 \pm 40 \mathrm{MPa}$ and 

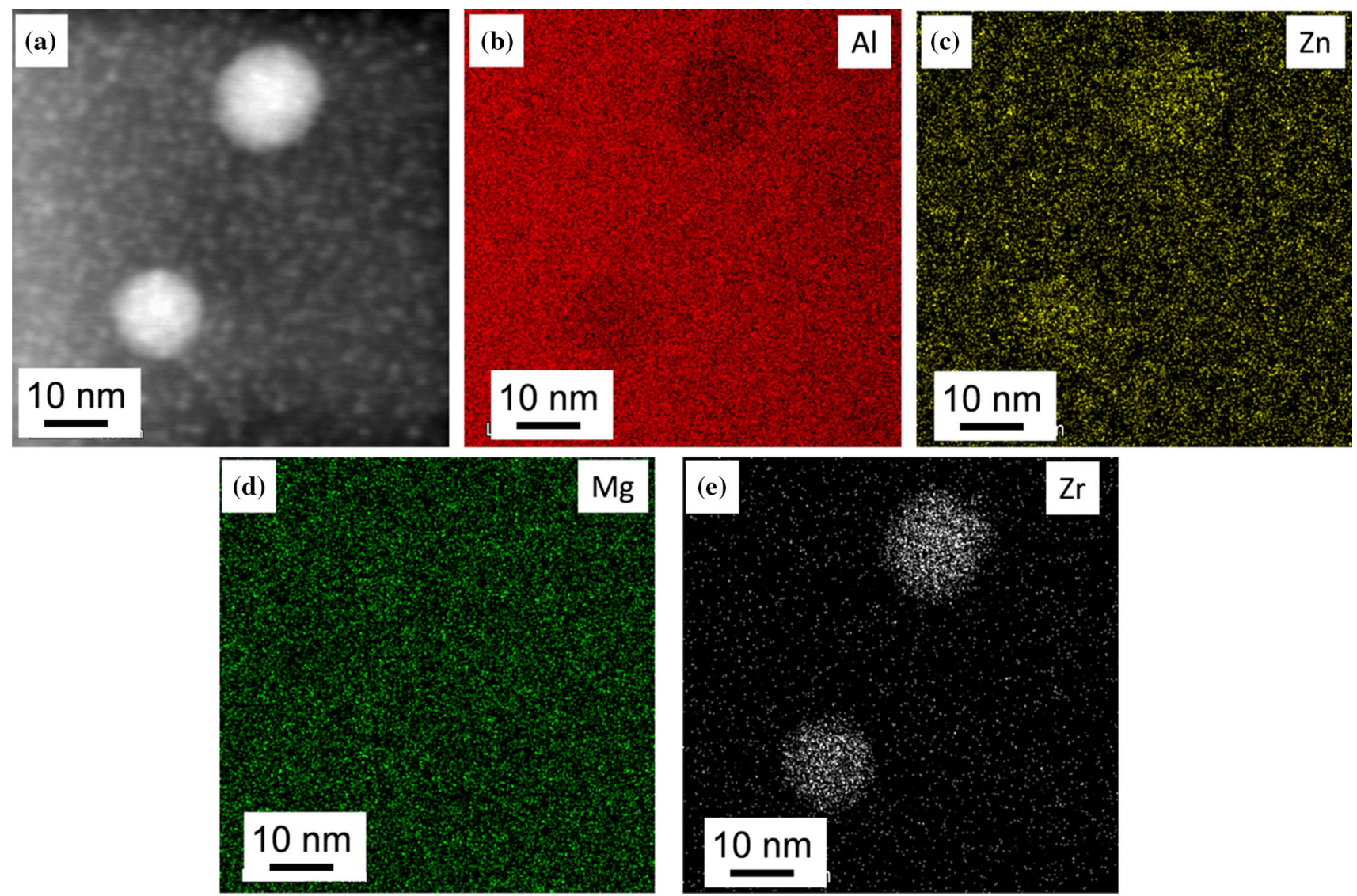

Figure 6 a HAADF STEM image showing precipitates in a sample quenched to RT after annealing at $470{ }^{\circ} \mathrm{C}$ for 30 min and stored at RT for 1 year. $\mathbf{b}-\mathbf{e}$ EDS elemental maps for $\mathrm{Al}, \mathrm{Zn}, \mathrm{Mg}$ and $\mathrm{Zr}$ obtained on the area shown in $\mathbf{a}$.

$1100 \pm 30 \mathrm{MPa}$, respectively, after aging at 120 and $170{ }^{\circ} \mathrm{C}$ for $2 \mathrm{~h}$. For the lower aging temperature, the TEM results have shown a slight change in the matrix microstructure, indicating the dissolution of a part of GP zones. The hardness reduction in this sample should be attributed to the change in GP zone- and/ or $\eta^{\prime}$ structure, as well as to the coarsening of $\mathrm{MgZn}_{2}$ precipitates. The growth of $\eta$ particles with an unchanged volume fraction usually results in softening since in this case dislocations overcome the incoherent precipitates with Orowan mechanism [3]. At the same time, during aging at $170{ }^{\circ} \mathrm{C}$ in addition to the significant change of the precipitate structure, the reduction of the dislocation density and grain growth also occurred, and all of these processes cause softening. Therefore, in the following the contributions of these processes to the hardness reduction will be estimated.

The hardness caused by dislocation strengthening $\left(\mathrm{HV}_{\mathrm{disl}}\right)$ can be expressed by the Taylor formula as:
$\mathrm{HV}_{\mathrm{disl}} \approx 3 \alpha M^{\mathrm{T}} G b \rho^{1 / 2}$

where $\alpha$ is a constant describing the dislocation strengthening (about 0.32 for $\mathrm{Al}$ [28]), $G$ is the shear modulus ( $\sim 26 \mathrm{GPa}$ for $\mathrm{Al}$ ), $b$ is the magnitude of the Burgers vector $(\sim 0.287 \mathrm{~nm}$ for $\mathrm{Al})$, and $M^{\mathrm{T}}$ is the Taylor factor. The alloys used in this investigation did not exhibit a strong texture and therefore $M^{\mathrm{T}}$ was taken as 3.06. The factor of three on the right-hand side of Eq. (1) represents the ratio of the hardness and the yield strength contributions of dislocations [29]. It should be noted that one-third of the hardness gives the flow stress at the plastic strain of $8 \%$ rather than the yield strength. However, for SPD-processed metallic materials the yield strength can be estimated as one-third of the hardness due to the low strain hardening. The values of $\mathrm{HV}_{\text {disl }}$ calculated from Eq. (1) are listed in Table 2. For the ECAP-processed sample, the contribution of dislocations to hardness was $480 \pm 60 \mathrm{MPa}$ which did not change during annealing at $120^{\circ} \mathrm{C}$. At the same time, aging at $170{ }^{\circ} \mathrm{C}$ resulted in a reduction of $\mathrm{HV}_{\text {disl }}$ to 
$400 \pm 50 \mathrm{MPa}$. The hardness caused by the precipitates $\left(\mathrm{HV}_{\text {precip }}\right)$ was calculated as the difference between the total measured hardness $\left(\mathrm{HV}_{\text {total }}\right)$ and the sum of the contributions of dislocations and lattice friction $\left(\mathrm{HV}_{0}\right)$ :

$\mathrm{HV}_{\text {precip }}=\mathrm{HV}_{\text {total }}-\left(\mathrm{HV}_{0}+\mathrm{HV}_{\text {disl }}\right)$.

The threshold hardness $\mathrm{HV}_{0}$ was estimated as three times the friction stress for $\mathrm{Al}$ $\left(\mathrm{HV}_{0}=60 \pm 10 \mathrm{MPa}\right.$ [28]). It is noted that grain boundary strengthening was not considered as a separate Hall-Petch term in Eq. (2). Former investigations (e.g., [28]) showed that Eq. (1) is able to incorporate both grain size and dislocation hardening effects for fcc metallic materials processed by SPD. This can be explained by the fact that in SPD-processed materials many dislocations are accumulated at grain boundaries. Therefore, when a dislocation glides in the vicinity of a grain boundary it interacts with the grain boundary dislocations and not directly with the grain boundary.

The values of $H V_{\text {precip }}$ obtained from Eq. (2) are also listed in Table 2. For the ECAP-processed specimen, the contribution of precipitates to the hardness is $930 \pm 110 \mathrm{MPa}$ which is much larger than that for dislocations $(480 \pm 60 \mathrm{MPa})$. During annealing at $120{ }^{\circ} \mathrm{C}, \mathrm{HV}_{\text {precip }}$ decreased to $690 \pm 110 \mathrm{MPa}$, i.e., it was still higher than the hardness caused by dislocation strengthening $(480 \pm 60 \mathrm{MPa})$. Aging at $170{ }^{\circ} \mathrm{C}$ yielded a decrease in both $\mathrm{HV}_{\text {disl }}$ and $\mathrm{HV}_{\text {precip, }}$ but the reduction of the contribution of precipitates was higher both relatively and absolutely compared to that of dislocations. Namely, the contributions of dislocations and precipitates to the decrease in the hardness are $\sim 80$ and $\sim 290 \mathrm{MPa}$, respectively. Thus, the softening during aging at both temperatures of 120 and $170{ }^{\circ} \mathrm{C}$ was caused mainly by the change of the precipitate structure, especially by the disappearance of GP zones formed during SPD.

\section{Conclusions}

The microstructure and the hardness of an UFG Al$\mathrm{Zn}-\mathrm{Mg}-\mathrm{Zr}$ alloy artificially aged at 120 and $170{ }^{\circ} \mathrm{C}$ for $2 \mathrm{~h}$ were studied. The UFG microstructure was obtained by four passes of ECAP at RT. The following conclusions were drawn from the experimental results:

1. ECAP resulted in an UFG microstructure with an average grain size of $\sim 260 \mathrm{~nm}$ and a high dislocation density of about $5 \times 10^{14} \mathrm{~m}^{-2}$. ECAP promoted precipitation since after four passes $\mathrm{MgZn}_{2}$ precipitates with the size of about $10 \mathrm{~nm}$ were formed while the quenched and naturally aged sample contained mainly GP zones with the average diameter of $\sim 2 \mathrm{~nm}$.

2. The artificial aging of the ECAP-processed sample at $120{ }^{\circ} \mathrm{C}$ for $2 \mathrm{~h}$ yielded a decrease in the hardness from $1470 \pm 40$ to $1230 \pm 40 \mathrm{MPa}$ due to a partial dissolution of GP zones and the coarsening of $\mathrm{MgZn}_{2}$ precipitates, especially in the vicinity of grain boundaries. The evolution of the heterogeneous precipitate structure can be explained by the elevated rate of diffusion along the grain boundaries. At the same time, significant grain growth and a decrease in the dislocation density were not observed, i.e., the softening can be attributed solely to the change of the precipitate structure.

3. Annealing at $170{ }^{\circ} \mathrm{C}$ for $2 \mathrm{~h}$ resulted in a considerable decrease in the dislocation density to $\sim 3.3 \times 10^{14} \mathrm{~m}^{-2}$, a grain growth in the matrix to about $530 \mathrm{~nm}$ and a large increase in the amount of $\mathrm{MgZn}_{2}$ precipitates. GP zones were not observed in this state of the material. The changes in the microstructure yielded a lower hardness for the sample aged at $170{ }^{\circ} \mathrm{C}$ $(1100 \pm 30 \mathrm{MPa})$ than that after annealing at $120{ }^{\circ} \mathrm{C}(1230 \pm 40 \mathrm{MPa})$.

4. For the ECAP-processed specimen, a significant amount (more than $60 \%$ ) of the hardness can be attributed to the strengthening effect of precipitates. This remained valid also for the samples
Table 2 The total measured microhardness $\left(\mathrm{HV}_{\text {total }}\right)$ and the calculated contributions of the lattice friction $\left(\mathrm{HV}_{0}\right)$, dislocations $\left(\mathrm{HV}_{\mathrm{disl}}\right)$ and precipitates $\left(\mathrm{HV}_{\text {precip }}\right)$

\begin{tabular}{lllll}
\hline Samples & $\mathrm{HV}_{\text {total }}(\mathrm{MPa})$ & $\mathrm{HV}_{0}(\mathrm{MPa})$ & $\mathrm{HV}_{\text {disl }}(\mathrm{MPa})$ & $\mathrm{HV}_{\text {precip }}(\mathrm{MPa})$ \\
\hline 4 ECAP at RT & $1470 \pm 40$ & $60 \pm 10$ & $480 \pm 60$ & $930 \pm 110$ \\
$4 \mathrm{ECAP}+$ aged at $120^{\circ} \mathrm{C}$ & $1230 \pm 40$ & $60 \pm 10$ & $480 \pm 60$ & $690 \pm 110$ \\
$4 \mathrm{ECAP}+$ aged at $170{ }^{\circ} \mathrm{C}$ & $1100 \pm 30$ & $60 \pm 10$ & $400 \pm 50$ & $640 \pm 90$ \\
\hline
\end{tabular}


aged after ECAP. The reduction of hardness during annealing was caused mainly by the change of the precipitate structure. For instance, during aging at $170{ }^{\circ} \mathrm{C}$ the contributions of dislocations and precipitates to the decrease in the hardness were $\sim 80$ and $\sim 290 \mathrm{MPa}$, respectively.

\section{Acknowledgements}

Open access funding provided by Eötvös Loránd University (ELTE). This research was supported by the Hungarian-Russian bilateral Research Program (TÉT) No. 2017-2.3.4-TÉT-RU-2017-00005. This work was financed partly by the Ministry of Human Capacities of Hungary within the ELTE University Excellence program (1783-3/2018/FEKUTSRAT). This work was also supported by the Project VEKOP2.3.3-15-2016-00002 of the European Structural and Investment Funds.

\section{Compliance with ethical standards}

Conflict of interest The authors declare that there is no conflict of interest.

Open Access This article is distributed under the terms of the Creative Commons Attribution 4.0 International License (http://creativecommons.org/ licenses/by/4.0/), which permits unrestricted use, distribution, and reproduction in any medium, provided you give appropriate credit to the original author(s) and the source, provide a link to the Creative Commons license, and indicate if changes were made.

\section{References}

[1] Mondolfo LF (1971) Structure of the aluminium: magnesium: zinc alloys. Int Metall Rev 153:95-124

[2] Polmear IJ (1995) Light alloys-metallurgy of the light metals, 3rd edn. Arnold, London

[3] Lendvai J (1996) Precipitation and strengthening in aluminium alloys. Mater Sci Forum 217-222:43-56

[4] Löffler H, Kovács I, Lendvai J (1983) Decomposition processes in Al-Zn-Mg alloys. J Mater Sci 18:2215-2240. h ttps://doi.org/10.1007/BF00541825

[5] Liddicoat PV, Liao XZ, Zhao Y, Zhu Y, Murashkin MY, Lavernia EJ, Valiev RZ, Ringer SP (2010) Nanostructural hierarchy increases the strength of aluminium alloys. Nat Commun 1:63. https://doi.org/10.1038/ncomms1062

[6] Watanabe K, Matsuda K, Ikeno S, Yoshida T, Murakami S (2015) TEM observation of precipitate structures in Al-Zn$\mathrm{Mg}$ alloys with addition of $\mathrm{Cu} / \mathrm{Ag}$. Metall Mater 60:977-979

[7] Wu C, Ma K, Zhang D, Wu J, Luo G, Zhang J, Chen F, Shen Q, Zhang L, Lavernia EJ (2017) Precipitation phenomena in $\mathrm{Al}-\mathrm{Zn}-\mathrm{Mg}$ alloy matrix composites reinforced with $\mathrm{B}_{4} \mathrm{C}$ particles. Sci Rep 7:9589. https://doi.org/10.1038/s41598-0 17-10291-4

[8] Bobruk E, Murashkin MY, Kazykhanov VU, Valiev RZ (2018) Superplastic behavior at lower temperatures of high strength ultrafine-grained Al alloy 7475. Adv Eng Mater 21:1800094. https://doi.org/10.1002/adem.201800094

[9] Wang D, Ma ZY (2009) Effect of pre-strain on microstructure and stress corrosion cracking of over-agaed 7050 aluminum alloy. J Alloys Compd 469:445-450

[10] Zhao YH, Liao XZ, Jin Z, Valiev RZ, Zhu YT (2004) Microstructures and mechanical properties of ultrafine grained $7075 \mathrm{Al}$ alloy processed by ECAP and their evolutions during annealing. Acta Mater 52:4589-4599

[11] Xu C, Furukawa M, Horita Z, Langdon TG (2005) Influence of ECAP on precipitate distributions in a spray-cast aluminum alloy. Acta Mater 53:749-758

[12] Xu C, Furukawa M, Horita Z, Langdon TG (2003) Using ECAP to achieve grain refinement, precipitate fragmentation and high strain rate superplasticity in a spray-cast aluminum alloy. Acta Mater 51:6139-6149

[13] Gubicza J, Schiller I, Chinh NQ, Illy J, Horita Z, Langdon TG (2007) The effect of severe plastic deformation on precipitation in supersaturated $\mathrm{Al}-\mathrm{Zn}-\mathrm{Mg}$ alloys. Mater Sci Eng A 460-461:77-85

[14] Samaee M, Najafi S, Eivani AR, Jafarian HR, Zhou J (2016) Simultaneous improvements of the strength and ductility of fine-grained AA6063 alloy with increasing number of ECAP passes. Mater Sci Eng A 669:350-357

[15] Ashrafizadeh SM, Eivani AR, Jafarian HR, Zhou J (2017) Improvement of mechanical properties of AA6063 aluminum alloy after equal channel angular pressing by applying a two-stage solution treatment. Mater Sci Eng A 687:54-62

[16] Duan ZC, Chinh NQ, Xu Ch, Langdon TG (2010) Developing processing routes for the equal-channel angular pressing of age-hardenable aluminum alloys. Metall Mater Trans 41A:802-809

[17] Chinh NQ, Lendvai J, Ping DH, Hono K (2004) The effect of $\mathrm{Cu}$ on mechanical and precipitation properties of $\mathrm{Al}-\mathrm{Zn}-$ Mg alloys. J Alloys Compd 378:52-60

[18] Dorward RC, Beerntsen DJ (1995) Grain structure and quench-rate effects on strength and toughness of AA7050 
$\mathrm{Al}-\mathrm{Zn}-\mathrm{Mg}-\mathrm{Cu}-\mathrm{Zr}$ alloy plate. Metall Trans A 26:2481-2484

[19] Chinh NQ, Juhász A, Tasnádi P, Lendvai J, Kovács I (1993) Effect of copper and zirconium upon the high temperature mechanical properties of AlMgZn alloys. Phys Stat Sol (a) 138:175-184

[20] Eivani AR, Zhou J, Duszczyk J (2012) A new approach to incorporating the effect of nano-sized dispersoids on recrystallization inhibition into Monte carlo simulation. Comput Mater Sci 54:370-377

[21] Buranova Y, Kulitskiy Peterlechner M, Mogucheva A, Kaibyshev R, Divinski SV, Wilde G (2017) Al3(Sc, Zr)based precipitates in $\mathrm{Al}-\mathrm{Mg}$ alloy: effect of severe deformation. Acta Mater 124:210-224

[22] Iwahashi Y, Wang J, Horita Z, Nemoto M, Langdon TG (1996) Principle of equal-channel angular pressing for the processing of ultra-fine grained materials. Scr Mater 35:143-146

[23] Furukawa M, Iwahashi Y, Horita Z, Nemoto M, Langdon TG (1998) The shearing characteristics associated with equalchannel angular pressing. Mater Sci Eng A 257:328-332

[24] Ribárik G, Gubicza J, Ungár T (2004) Correlation between strength and microstructure of ball-milled $\mathrm{Al}-\mathrm{Mg}$ alloys determined by X-ray diffraction. Mater Sci Eng A 387-389:343-347

[25] Ungár T, Tichy G, Gubicza J, Hellmig RJ (2005) Correlation between subgrains and coherently scattering domains. Powder Diffr 20:366-375

[26] Priya P, Krane MJM, Johnson DR (2016) Precipitation of $\mathrm{Al}_{3} \mathrm{Zr}$ dispersoids during homogenization of $\mathrm{Al}-\mathrm{Zn}-\mathrm{Cu}-$ $\mathrm{Mg}-\mathrm{Zr}$ alloys. In: Williams E (ed) Light metals 2016. Springer, Cham, pp 213-218

[27] Gubicza J, Schiller I, Chinh NQ, Illy J, Horita Z, Langdon TG (2007) The effect of severe plastic deformation on precipitation in supersaturated $\mathrm{Al}-\mathrm{Zn}-\mathrm{Mg}$ alloys. Mater Sci Eng A 460-461:77-85

[28] Gubicza J, Chinh NQ, Lábár JL, Hegedűs Z, Xu C, Langdon TG (2008) Microstructure and yield strength of severely deformed silver. Scr Mater 58:775-778

[29] Tabor D (1951) Hardness of metals. Clarendon Press, Oxford

Publisher's Note Springer Nature remains neutral with regard to jurisdictional claims in published maps and institutional affiliations. 